\title{
UPAYA KONSERVASI INDONESIA ATAS SUMBER DAYA IKAN DI LAUT LEPAS
}

\section{Indonesia Conservation Efforts to Resources of Fish in the High Seas}

\author{
Muhammad Insan Tarigan \\ Universitas Gadjah Mada, Yogyakarta \\ email: insantarigan02@gmail.com
}

\begin{abstract}
The principle of freedom of fishing on the high seas was recognized as one of the principles in customary international law, the Geneva Convention on the High Seas1958, and Part VII of UNCLOS 1982. Regarding to thehigh level of utilization of fish led to the crisis of fishery resources, then the responsible fisheries management becomes a common agenda of the international community. Thisresearch is a normative legal research, data collection was done through studyliterature and documentaries on the primary and secondarylegal materials related to this problem.After conductedthe identification and classification of the data, then data was analysed normatively. There are some international conventions as a basis for maintainingthe conservation of fish on the high seas. UNCLOS 1982, the 1993 FAO Compliance Agreement, the Code of Conduct for Responsible Fisheries (CCRF) in 1995, the IPOA-IUU Fishing, 2001. The result showed thatIndonesia has had several regulations concerning to fisheries, such as Law Number 31 of 2004 concerning to Fisheries and Law Number 45 of 2009 concerning to Fisheries, and the Minister of Marine and Fisheries Regulation Number PER.03/MEN/2009 on Fishing and/or Transporting Fish on the High Seas and the Ministerial Regulation Number Per.12/Men/2012 concerning toEnterprises Capture Fishery on the High Seas. The Government of Indonesia should be able to take advantage of such participation and to improve the exchange of information, data, research fisheries, combating illegal arrests, and other forms of cooperation.
\end{abstract}

Keywords: High Seas, Fish Resources, Indonesia, conservation

\section{abstrak}

Prinsip kebebasan menangkap ikan di laut lepas memang diakui sebagai salah satu prinsip yang dijamin dalam kebiasaan hukum internasional, the Geneva Convention on the High Seas 1958, dan Bagian VII UNCLOS 1982. Dengan berkaca pada tingginya tingkat pemanfaatan ikan yang 
dikhawatirkan berujung pada krisis sumber daya ikan, maka pengelolaan perikanan yang bertanggung jawab telah menjadi agenda bersama masyarakat internasional. Penelitian ini adalah penelitian hukum normatif (normative legal research), dengan teknik pengumpulan data dilakukan melalui studi pustaka dan dokumenter terhadap bahan hukum primer maupun bahan hukum sekunder yang terkait dengan permasalahan ini. Setelah dilakukan proses identifikasi dan klasifikasi, dilakukan analisis normatif atas data-data tersebut. Ada beberapa peraturan internasional yang dapat dijadikan sebagai dasar bagi setiap pihak yang memiliki kapasitas untuk menjaga konservasi ikan di laut lepas. UNCLOS 1982, FAO Compliance Agreement 1993, Code of Conduct for Responsible Fisheries (CCRF) 1995, IPOA-IUU Fishing 2001. Indonesia telah membuat regulasi tentang perikanan melalui Undang-Undang Nomor 31 Tahun 2004 tentang Perikanan dan Undang-Undang Nomor 45 Tahun 2009 tentang Perikanan, serta Peraturan Menteri Kelautan dan Perikanan Nomor PER.03/MEN/2009 tentang Penangkapan Ikan dan/atau Pengangkutan Ikan di Laut Lepas dan Peraturan Menteri Nomor Per.12/Men/2012 tentang Usaha Perikan Tangkap di laut lepas. Hasil penelitian menunjukkan bahwa Indonesia memiliki kedudukan setelah bergabung dengan beberapa organisasi regional dalam upaya konservasi sumber daya ikan di laut lepas. Pemerintah Indonesia harus mampu memanfaatkan keikutsertaan dalam organisasi regional tersebut serta meningkatkan pertukaran informasi, data, riset perikanan, pemberantasan penangkapan ikan secara ilegal, dan bentuk-bentuk kerja sama lainnya.

\section{Kata Kunci: Laut Lepas, Sumber daya Ikan, Indonesia, konservasi}

\section{A. Pendahuluan}

Indonesia sebagai sebuah negara kepulauan yang sebagian besar wilayahnya terdiri dari laut, memiliki potensi perikanan yang sangat besar dan beragam. Potensi perikanan yang dimiliki merupakan potensi ekonomi yang dapat dimanfaatkan untuk masa depan bangsa, sebagai tulang punggung pembangunan nasional. Pemanfaatan secara optimal diarahkan pada pendayagunaan sumber daya ikan dengan memperhatikan daya dukung yang ada dan kelestariannya untuk meningkatkan kesejahteraan rakyat, meningkatkan taraf hidup nelayan kecil dan pembudi daya ikan kecil, meningkatkan penerimaan devisa negara, menyediakan perluasan dan kesempatan kerja, meningkatkan produktivitas, nilai tambah dan daya saing hasil perikanan serta menjamin kelestarian sumber daya ikan, lahan pembudidayaan ikan serta tata ruang. Hal ini berarti bahwa pemanfaatan sumber daya perikanan harus seimbang dengan daya dukungnya, sehingga diharapkan dapat memberikan manfaat secara terus menerus. Salah satunya 
dilakukan dengan pengendalian usaha perikanan melalui pengaturan pengelolaan perikanan.

Indonesia merupakan negara kepulauan (archipelagic state) terbesar di dunia. Sebagai negara kepulauan terbesar dapat dipastikan bahwa sumber daya ikan juga melimpah didalamnya. Hal tersebut dapat dilihat pada produksi perikanan pada tahun 2014 mencapai 20,72 juta ton, yang terdiri dari produksi perikanan tangkap sebesar 6,72 juta ton dan produksi perikanan budidaya sebesar 14,52 ton. ${ }^{1}$ Bahkan, Indonesia juga dapat memanfaatkan sumber daya ikan di perairan laut lepas (high seas). Hal ini dikarenakan, posisi perairan Indonesia yang berhadapan langsung dengan dua perairan internasional, yaitu Samudera Hindia dan Samudera Pasifik. Tentu saja, pemanfaatan sumber daya ikan di perairan laut lepas oleh suatu negara pantai (coastal state) di dasarkan pada asas kekebasan yang melekat pada rezim laut lepas.

Terkait kegiatan penangkapan ikan, FAO memperkirakan bahwa pada tahun 2006 terdapat kapal-kapal penangkap ikan bermesin sebanyak 2,1 juta, di mana 70\% nya terkonsentrasi di Asia dan sisanya tersebar di Afrika, Eropa, Timur Dekat, Amerika Latin dan Karibia. 90\% dari jumlah tersebut didominasi oleh kapal-kapal yang berukuran kurang dari 12 meter, khususnya di wilayah Asia, Afrika dan Timur Jauh, sedangkan kapal-kapal di kawasan Pasifik, Oceania, Eropa dan Amerika Utara umumnya terdiri dari kapal-kapal yang berukuran lebih besar.

Dalam kurun waktu 40 tahun, sejak 1950-1990, diperkirakan hasil tangkapan (total landings) perikanan laut meningkat lima kali lipat. Namun demikian, upaya penangkapan ikan tidak mampu mengimbangi permintaan yang semakin meningkat sementara banyak dari perikanan laut telah melampaui batas penangkapan (overfished). FAO memperkirakan dalam periode 1990-1997, konsumsi ikan meningkat sebesar 31\% sementara pemenuhan dari tangkapan ikan hanya bertambah sebesar 9\%. Hal ini pada gilirannya telah meningkatkan tekanan pada usaha-usaha penangkapan ikan komersial. Diperkirakan bahwa hampir setengah dari seluruh perikanan laut telah tereksploitasi dan $70 \%$ diantaranya membutuhkan pengelolaan segera. Selanjutnya, pada tahun 2002 total penangkapan perikanan laut 84,5 juta ton. Setelah mencapai angka 80 juta ton pada tahun 1980-an, tangkapan perikanan laut dunia berfluktuasi antara 77 dan 86 juta ton dengan catatan tertinggi 86,8 juta ton pada tahun 2000 dan menurun menjadi 81,5 juta ton pada tahun 2003. Informasi lain yang diperoleh dari data statistik perikanan FAO tahun 2007 adalah, total produksi perikanan tangkap dunia sejak tahun 2000 berkisar di atas angka 90\% dari total produksi perikanan dunia, yaitu

\footnotetext{
${ }^{1}$ Peraturan Menteri Kelautan dan Perikanan Republik Indonesia Nomor 25/Permen-KP/2015 tentang Rencana Strategis Kementerian Kelautan dan Perikanan Tahun 2015-2019.
} 
tahun 2000 (95,6\%), 2001 (93,1\%), 2002 (93,3\%), 2003 (90,5\%), 2004 $(95,0 \%)$, dan $2005(93,8 \%){ }^{2}$ Selain itu, data FAO menyebutkan bahwa sekarang ini gejala tangkap lebih (overfishing) di tingkat internasional semakin meluas, yaitu $17 \%$ overexploited, $52 \%$ fully exploited, $7 \%$ depleted, $1 \%$ underexploited, $20 \%$ moderatley exploited, dan $1 \%$ slowly recovering. ${ }^{3}$

Ekosistem ikan juga mengalami krisis yang diakibatkan oleh polusi air dan degradasi habitat, di mana kapal-kapal melakukan pencemaran di laut dengan membuang sampah dan limbah serta terjadinya tumpahan minyak oleh kapal. Beberapa kasus penangkapan ikan dengan menggunakan alat-alat tangkap yang bersifat destruktif juga membawa akibat merugikan pada lingkungan laut. Penggunaan tropical shrimp trawling, misalnya, tidak hanya mampu menangkap ikan namun juga dapat mengakibatkan ikut terbawanya penyu laut sebagai bycatch. ${ }^{4}$ Para nelayan juga banyak menggunakan bottom trawling, yaitu penggunaan jaring besar yang ditebarkan hingga ke dasar laut sehingga menjaring tidak hanya ikan namun juga hewan laut dan organisme lainnya seperti terumbu karang yang mengancam keanekaragaman hayati (biodiversity) serta lingkungan laut. ${ }^{5}$

Prinsip kebebasan menangkap ikan di laut lepas memang diakui sebagai salah satu prinsip yang dijamin dalam kebiasaan hukum internasional, the Geneva Convention on the High Seas, dan Bagian VII UNCLOS 1982. Prinsip ini misalnya dapat dirujuk dalam putusan arbitrase Behring Sea Fur Seals (1893) yang menolak klaim Inggris atas kapasitasnya untuk menahan kapal Amerika Serikat yang melakukan penangkapan fur seal di laut lepas, berdasarkan peraturan perlindungan dan konservasi. ${ }^{6}$

Namun demikian, tarik menarik antara kebebasan menangkap ikan dan kebutuhan penerapan aturan konservasi di laut lepas, sebagaimana diilustrasikan dalam kasus laut Behring tersebut, kiranya telah menjadi kunci dalam memahami dua perkembangan hukum penting yang terjadi hingga saat ini. Pertama, adanya perubahan aturan mengenai perikanan di laut lepas oleh regional treaties untuk menjamin konservasi, pembangunan stok ikan

${ }^{2}$ Akhmad Solihin, "Perikanan Indonesia dalam Kepungan Organisasi Pengelolaan Perikanan Regional dan Internasional", www.pksplipb.or.id, diakses pada pukul 13.08 WIB, tanggal 30 Januari 2016.

${ }^{3}$ James H. Tidwell \& Geoff L. Allan, Ecological and economic impacts and contributions of fish farming and capture fisheries, http://www.nature.com/embor/journal/v2/n11/full/ embor285.html, diakses pada pukul 13.30 WIB, tanggal 10 Juni 2015.

${ }^{4}$ Global fisheries face the ecosystem challenge. ftp://ftp.fao.org/docrep/fao/011/aj982e/aj982 e09.pdf, diakses pada pukul 14.00 WIB, tanggal 10 Juni 2015.

${ }^{5}$ Conservation Science Institute, Destructive Fishing Practices, 2009, http://www.conser vationinstitute.org/ocean_change/Fisheries/destructivefishingpractices.htm, diakses pada pukul 14.25 WIB, tanggal 10 Juni 2015.

${ }^{6}$ Oppenheim's, International law, Ninth Edition 1996, Edited by Sir Robert Jennings QC and Sir Arthur Watts KCMG QC, Volume 1, Longman, hlm. 757. 
(fish stocks), dan distribusi hasil laut yang lebih adil. Kedua, perluasan yurisdiksi perikanan nasional oleh negara pantai sampai dengan 200 mil dari garis batas laut teritorial, atau yang dikenal dengan zona ekonomi eksklusif. ${ }^{7}$

Bagi negara-negara berkembang yang berpantai, perluasan laut wilayah sejauh 200 mil laut merupakan reaksi atas prinsip kebebasan di laut dari kapal-kapal penangkap ikan negara-negara maritim besar yang mengarungi semua lautan dan samudera dan melakukan kegiatankegiatannya di laut-laut dekat perairan nasional negara-negara pantai. Selanjutnya, dikarenakan negara-negara pantai tersebut merasa lebih berhak dari negara-negara lain telah memutuskan untuk mencadangkan kekayaankekayaan laut yang berdekatan dengan perairannya untuk kesejahteraan rakyat mereka. ${ }^{8}$ Dengan demikian, konsepsi ZEE merupakan manifestasi dari usaha-usaha negara-negara pantai untuk melakukan pengawasan dan penguasaan terhadap segala macam sumber kekayaan yang terdapat di zona laut yang terletak di luar dan berbatasan dengan laut wilayahnya. ${ }^{9}$

Dalam konteks regional, pada beberapa negara pantai yang sedang berkembang di kawasan Asia Selatan dan Asia Tenggara, seperti Bangladesh, Brunei Darussalam, Kamboja, India, Indonesia, Srilanka, Thailand dan Vietnam, total tangkapan hasil perikanan meningkat dari 5,5 juta ton pada tahun 1970 menjadi 15,6 juta ton pada tahun $2000 .{ }^{10}$ Namun demikian, peningkatan produksi perikanan di kawasan Asia Selatan dan Asia Tenggara, pada beberapa negara telah terjadi penurunan tangkapan sejak tahun 1990, seperti India, Filipina dan Thailand. ${ }^{11}$

Dengan berkaca pada tingginya tingkat pemanfaatan yang dikhawatirkan berujung pada krisis sumber daya ikan, maka pengelolaan perikanan yang bertanggung jawab telah menjadi agenda bersama masyarakat internasional. Hal ini dikarenakan, terganggunya kelestarian sumber daya ikan di satu negara akan mempengaruhi kondisi perikanan global dan dapat menyebabkan stok ikan di negara lain juga ikut terganggu, khususnya jenis-jenis ikan yang bermigrasi jauh (higly migratory species) dan jenis-jenis ikan yang bermigrasi terbatas (straddling fish stock) yang memunyai kemampuan untuk melintasi batas-batas wilayah suatu negara (transboundary). Dengan demikian, masyarakat internasional tidak selalu berurusan dengan kepentingan individu dari setiap anggotanya, demikian

\footnotetext{
${ }^{7}$ Ibid.

${ }^{8}$ Boer Mauna, Hukum Internasional, Pengertian Peranan dan Fungsi Dalam Era Dinamika Global, Edisi ke-2, (Penerbit PT. Alumni, 2005), hlm. 359.

${ }^{9}$ Ibid.

${ }^{10}$ Purwito Martosubroto, Implementing of the Code of Conduct for Responsible Fisheries in the Marine Fisheries Sector, Lembaga Pengkajian Hukum Internasional, Jakarta, Jurnal Hukum Internasional, Vol 2, No. 3, April 2005, hlm. 5.

${ }^{11}$ Ibid.
} 
juga setiap anggota masyarakat internasional tidak selalu berurusan dengan kepentingan nasionalnya, melainkan ada pula saat yang mengharuskan mereka berurusan dengan kepentingan bersama, masalah-masalah bersama, yang harus dipecahkan secara bersama-sama. ${ }^{12}$

Asas kebebasan di laut lepas sebagaimana yang disebutkan di atas harus mengindahkan kepentingan negara lain dalam melaksanakan hak yang sama dan ketentuan internasional lain yang berlaku di atasnya. Khusus untuk kegiatan penangkapan ikan, diperkuat lagi hak dari suatu negara untuk mengirimkan armada perikanan nasionalnya ke laut bebas (Pasal 116 UNCLOS 1982). Akan tetapi, pelaksanaan kebebasan ini harus dibarengi dengan diindahkannya ketentuan mengenai langkah-langkah konservasi sumber daya hayati di laut lepas. Langkah ini dapat dilakukan secara unilateral maupun bekerja sama dengan negara lain. Dorongan adanya kerja sama antara negara-negara yang memanfaatkan sumber daya hayati di laut lepas yang sama ditekankan dalam Pasal 118 UNCLOS 1982, di mana negara-negara harus mengatur pengelolaan dan konservasi tersebut, apabila memungkinkan dengan membentuk organisasi-organisasi pengelolaan perikanan regional (Regional Fisheries management Organizations/RFMOs) di berbagai kawasan yang memunyai aturan sendiri dalam mengelola kegiatan perikanan.

Hingga saat ini, terdapat 13 Regional Fisheries Management Organizations (RFMOs) di seluruh dunia. Pada kawasan Samudera Atlantik terdapat North-West Atlantic Fisheries Organization (NAFO), North-East Atlantic Fisheries Convention (NEAFC), North Atlantic Salmon Conservation Organization (NASCO), International Commission for the Conservation of Atlantic Tuna (ICCAT), Fishery Committee for the Eastern Central Atlantic (CECAF), Western Central Atlantic Fishery Commission (WECAFC), dan South-East Atlantic Fisheries Organization (SEAFO). ${ }^{13}$

Pada kawasan Mediterania terdapat General Fisheries Council for the Mediterranean (GFCM), Samudera Hindia memiliki Indian Ocean Tuna Commission (IOTC) dan Commission for the Conservation of Southern Blufin Tuna (CCSBT), serta Antartik memunyai Commission for the Conservation of Antartic Marine Living Resources (CCAMLR). Sementara itu, di Samudera Pasifik dapat pula dijumpai Commission for the Conservation and Management of Highly Migratory Fish Stocks in the Western and Central Pacific Ocean (WCPFC) dan Inter-American Tropical Tuna Commission (IATTC). ${ }^{14}$

\footnotetext{
${ }^{12}$ Ibid.

${ }^{13}$ Hari Yulianto, Qua Vadis Arah Kebijakan Perikanan Indonesia? Tantangan Dalam Perspektif Hukum dan Kepentingan Nasional (bagian I), Opinio Juris, Vol. I, Januari-Maret 2010, hlm. 12.

${ }^{14}$ Ibid.
} 
Selain merupakan lintas perjalanan ikan-ikan yang berupaya jauh, perairan Indonesia juga merupakan tempat pemijahan, misalnya southern bluefin tuna yang berada di Samudera Hindia sebelah selatan Jawa dan Bali. Indikasi menunjukkan bahwa tangkapan (catch rate) baik di Samudera Hindia maupun Samudera Pasifik terlihat lebih tinggi di laut lepas dibandingkan ZEEI sehingga hal itu mendorong kapal-kapal Indonesia banyak menangkapnya di laut lepas. Adapun sumber daya highly migratory fish stock ini secara global sudah hampir jenuh dieksploitasi. Hal ini ditandai dengan penurunan hasil tangkapan, rata-rata ukuran ikan yang tertangkap semakin kecil, serta daerah penangkapannya semakin jauh. ${ }^{15}$

Peraturan mengenai sumber daya perikanan yang dimiliki Indonesia saat ini adalah Undang-Undang Nomor 31 Tahun 2004 tentang Perikanan (Lembaran Negara Republik Indonesia Tahun 2004 Nomor 118). UndangUndang Nomor 31 Tahun 2004 merupakan rujukan dari diratifikasinya UNCLOS 1982 dengan Undang-Undang No. 17 Tahun 1985 tentang Pengesahan United Nations Convention on The Law of the Sea (Konvensi Perserikatan Bangsa-Bangsa Tentang Hukum Laut). Sebagai konsekuensi hukum diratifikasinya UNCLOS 1982, Indonesia memiliki hak untuk melakukan pemanfaatan, konservasi, dan pengelolaan sumber daya ikan di ZEEI dan laut lepas yang dilaksanakan berdasarkan persyaratan atau standar internasional yang berlaku. ${ }^{16}$

Pasal 3 Undang-Undang Nomor 31 Tahun 2004 tentang Perikanan, tujuan pengelolaan perikanan antara lain adalah menjamin kelestarian sumber daya ikan, lahan pembudidayaan ikan, dan tata ruang. Dalam Undang-Undang Nomor 31 Tahun 2004, ketentuan mengenai pengelolaan perikanan diatur dalam Bab IV tentang pengelolaan perikanan. Mengenai kerja sama internasional pengelolaan sumber daya perikanan terdapat dalam Pasal 10, antara lain kewajiban negara dalam mempublikasikan secara berkala hal-hal yang berkenaan dengan langkah konservasi dan pengelolaan sumber daya ikan, dan juga keikutsertaan pemerintah dalam keanggotaan organisasi atau badan pengelolaan perikanan regional maupun internasional. Berdasarkan uraian di atas, penulis mencoba melakukan penelitian yang akan dituangkan dalam bentuk makalah dengan judul "Indonesia dan Upaya Konservasi Sumber Daya Ikan di Laut Lepas". Adapun masalah yang dapat ditelusuri lebih jauh berdasarkan uraian pada latar belakang di atas adalah sebagai berikut: 1) Bagaimanakah pengaturan hukum internasional tentang konservasi stok ikan di laut lepas?; dan 2) Bagaimanakah kedudukan Indonesia terhadap upaya perlindungan stok ikan di laut lepas?

\footnotetext{
${ }^{15}$ Marhaeni Ria Siombo, Hukum Perikanan Nasional dan Internasional, (Jakarta: Gramedia Pustaka Utama, 2010), hlm. 85.

${ }^{16}$ Penjelasan Ketentuan Umum Undang-Undang Nomor 31 Tahun 2004 tentang Perikanan.
} 
Penelitian yang dilakukan adalah penelitian hukum normative, yaitu penelitian yang mengaji hukum tertulis dari berbagai aspek-aspek seperti aspek teori, sejarah, filosofis, perbandingan, struktur dan komposisi, lingkup dan materi, konsistensi, penjelasan umum dan pasal demi pasal, serta formalitas dan kekuatan mengikat suatu peraturan perundang-undangan, penelitian ini juga sering disebut penelitian hukum dogmatik atau penelitian hukum teoretis. ${ }^{17}$ Penelitian hukum normatif dalam penelitian ini menggunakan penelitian kepustakaan (library research) sebagai sumber utama. Bahan pustaka merupakan data dasar dalam penelitian ini atau digolongkan sebagai data sekunder dalam ilmu penelitian. Data sekunder yang digunakan dalam penelitian ini meliputi, konvensi internasional, peraturan perundang-undangan Indonesia, buku-buku termasuk skripsi, tesis, dan desertasi hukum serta jurnal-jurnal hukum. Pengumpulan data dilakukan melalui kegiatan studi pustaka baik di perpustakaan umum maupun perpustakaan khusus di bidang hukum. Data-data yang telah terkumpul, maka selanjutnya adalah menganalisis data-data tersebut. Jenis penelitian ini adalah penelitian hukum normatif, maka data-data yang terkumpul dalam penelitian hukum ini dianalisis secara deskriptif kualitatif, yaitu dengan melalukan analisis yang pada dasarnya dikembalikan kepada tiga aspek, yaitu mengklasifikasi, membandingkan, dan menghubungkan.

\section{B. Pembahasan}

\section{Instrumen Hukum Internasional tentang Konservasi Stok Ikan Laut di Laut Lepas}

Laut lepas merupakan semua bagian dari laut yang tidak termasuk dalam zona ekonomi eksklusif, laut teritorial, perairan pedalaman suatu negara, atau dalam perairan kepulauan suatu negara kepulauan. Implikasi dari definisi tersebut membuat laut lepas menjadi kawasan yang terbuka bagi setiap negara dan tidak ada negara yang mengklaim bahwa kawasan tersebut berada di bawah yurisdiksinya. ${ }^{18}$ Jawahir Thontowi dan Prannoto Iskandar dalam bukunya menyatakan bahwa pada prinsipnya di laut lepas tidak berlaku kedaulatan, hak berdaulat atau yurisdiksi suatu negara, laut lepas merupakan res communis, yaitu laut yang terbuka dan bebas bagi semua negara. ${ }^{19}$ Rezim yang melekat ini menjadikan laut lepas dapat digunakan atau dimanfaatkan oleh negara manapun.

\footnotetext{
${ }^{17}$ Abdulkadir Muhammad, Hukum dan Penelitian Hukum, (Bandung: Citra Aditya Bakti, 2004), hlm. 101-102.

${ }^{18}$ R.R. Churchill and A.V. Lowe, The Law Of The Sea, (Manchester: Manchester University Press, 1983), hlm. 204.

19 Jawahir Thontowi dan Pranoto Iskandar, Hukum Internasional Kontemporer, (Bandung, PT. Refika Aditama, 2006), hlm. 189.
} 
Pengaturan laut lepas (high seas) terdapat dalam Konvensi-Konvensi Jenewa yang merupakan hasil dari Konferensi PBB tentang Hukum Laut (UNCLOS) I tanggal 24 Februari-27 April 1958. Pasal 1 Konvensi Jenewa 1958 tersebut memberikan pengertian laut lepas yang berbunyi bahwa laut lepas adalah semua bagian laut yang tidak termasuk laut teritorial atau perairan pedalaman suatu Negara. Konvensi Jenewa 1958 ini sudah tidak berlaku lagi karena ada yang baru, yaitu Konvensi Hukum Laut 1982. Konvensi Hukum Laut 1982 dalam Pasal 86 menyatakan pengertian laut lepas sebagai berikut yaitu bahwa laut lepas adalah semua bagian laut yang tidak termasuk zona ekonomi eksklusif, laut teritorial atau perairan pedalaman suatu negara dan perairan kepulauan dalam negara kepulauan.

Pengertian laut lepas menurut Konvensi Hukum Laut 1982 ini sangat jauh statusnya dengan pengertian laut lepas menurut Konvensi Jenewa 1958. Laut lepas menurut Konvensi Jenewa 1958 adalah hanya 3 mil dari laut teritorial, sedangkan laut lepas menurut Konvensi Hukum Laut 1982 adalah dimulai dari zona ekonomi eksklusif yang berarti dimulai dari 200 mil. Menurut Konvensi Hukum Laut 1982, laut teritorial yang sejauh 12 mil itu tunduk pada kedaulatan penuh suatu Negara, sedangkan zona ekonomi eksklusif yang sejauh itu memunyai status sui generic, yaitu bahwa sifat khusus yang bukan bagian dari kedaulatan negara, tetapi juga tidak tunduk pada rezim internasional. Dalam zona ekonomi eksklusif, setiap negara memunyai hak-hak berdaulat dan yurisdiksi sebagaimana dijelaskan di atas.

Laut lepas adalah res nullius, konsep ini diajukan oleh orang-orang Belanda ajaran Grotius, menurut mereka, laut tidak bertuan, jadi siapapun boleh mengarungi lautan, tanpa keberatan dari pihak manapun. Dengan konsep inilah pelaut-pelaut Belanda bisa pergi ke seberang lautan, mencari dan menyusuri apa saja yang penting bagi mereka. Alhasil mereka menemukan Tazmania, Ambon, Maluku, dll. Itulah latar belakang singkat terbentuknya VOC yang kerjanya cari komoditas untuk diperdagangkan (mencari untung). Dan kecuali apabila terdapat aturan-aturan pengecualian dan batasan-batasan yang diterapkan untuk kepentingan negara-negara, laut lepas tidak merupakan wilayah negara manapun. Doktrin laut bebas (freedom of the sea) berarti bahwa kegiatan-kegiatan di laut dapat dilakukan dengan bebas dengan mengindahkan penggunaan laut untuk keperluan lainya. ${ }^{20}$

Istilah laut lepas yang dikenal dengan sebutan high seas atau open seas merupakan bagian wilayah laut yang tidak termasuk laut teritorial atau laut intern, yaitu laut yang termasuk ke dalam garis dasar laut teritorial. Secara historis, pernah ada sejumlah negara yang ingin menguasai samudera,

\footnotetext{
${ }^{20}$ Chairul Anwar, Hukum Internasional Horizon Baru Hukum Laut Internasional Konvensi Hukum Laut 1982, (Jakarta, Penerbit Djambatan, 1989), hlm. 62.
} 
seperti Portugal di Samudera Hindia, Spanyol di Samudera Pasifik, Inggris di Terusan Inggris. Namun, Grotius keberatan dengan menyatakan bahwa laut lepas tidak selayaknya berada di bawah yurisdiksi suatu negara dengan alasan:

1. samudera tidak dapat menjadi milik sesuatu negara, karena tiada negara dapat menduduki secara efektif; dan

2. alam tidak memperbolehkan seseorang memiliki sesuatu yang dapat dipergunakan oleh setiap negara. Laut lepas dinamakan pula res gentium atau res extra commercium.

Sejumlah ketentuan di laut lepas sebagaimana dikemukakan oleh J.G Starke sebagai berikut: ${ }^{21}$

1. bahwa laut lepas tidak dapat diletakkan di bawah kedaulatan suatu negara tertentu. bahwa terdapat kebebasan mutlak menangkap ikan di laut lepas ini bagi kapal-kapal semua bangsa, baik niaga maupun kapal perang;

2. bahwa pada umumnya, suatu negara tidak boleh menjalankan yurisdiksi atas kapal yang tidak memakai bendera negaranya;

3. bahwa negara hanya dapat menjalankan yurisdiksi atas kapal tertentu yang mengibarkan benderanya;

4. bahwa setiap negara dan warganya berhak menggunakan laut lepas, misalnya untuk memasang kawat/kabel serta pipa di dasar laut (freedom of immersion); dan

5. bahwa terdapat kebebasan mutlak penerbangan di atas laut lepas bagi semua pesawat.

Berdasarkan prinsip kebebasan, semua negara baik negara berpantai atau tidak, dapat menggunakan laut lepas dengan syarat mematuhi ketentuan-ketentuan yang ditetapkan oleh konvensi atau ketentuan-ketentuan hukum internasional lainnya. Menurut Pasal 87 Konvensi Hukum Laut 1982, kebebasan tersebut meliputi:

1. freedom of navigation;

2. freedom of overflight;

3. freedom to lay submarine cables and pipelines, subject to Part VI;

4. freedom to construct artificial islands and other installations permitted under international law, subject to Part VI;

5. freedom of fishing, subject to the conditions laid down in section 2; and

6. freedom of scientific research, subject to Parts VI and XIII.

Kebebasan-kebebasan tersebut harus dilaksanakan oleh setiap negara dengan memperhatikan hak negara lain dalam melakukan hak-hak kebebasan di laut lepas berdasarkan syarat-syarat yang ditentukan dalam Konvensi Hukum Laut 1982 dan ketentuan lain dalam Hukum Internasional. Laut lepas sebagaimana disebutkan dalam Pasal 87 UNCLOS merupakan

${ }^{21}$ J.G.Starke, An Introduction to International law. (London, Butterworths, 1988), hlm. 57. 
laut yang terbuka bagi semua negara, sehingga memungkinkan terjadinya suatu tindak pidana pada kawasan tersebut, seperti pembajakan kapal, perdagangan gelap dan penyiaran yang tidak sah. Dalam hal ini setiap negara berkewajiban untuk bekerja sama di laut manapun di luar yurisdiksi suatu negara termasuk di laut lepas dalam pemberantasan penangkapan ikan yang berlebihan, pembajakan kapal, perdagangan gelap obat narkotik dan bahanbahan psikotropis, serta siaran gelap. ${ }^{22}$ Dampak yang paling rentan dari segala tindakan di laut lepas yaitu berkurangnya stok sumber daya hayati.

Dari enam prinsip kebebasan di laut lepas tersebut, salah satunya adalah prinsip kebebasan melakukan penangkapan ikan. Kebebasankebebasan tersebut bukan merupakan sebuah kebebasan yang memberikan kekuasaan bagi pihak manapun, tetapi kebebasan diberikan dengan konsep perlindungan, sehingga kegiatan yang dilakukan di wilayah laut lepas tidak sampai merusak perairan dan sumber daya alam hayatinya.

Menurut sejarah, pada tanggal 28 September 1945 Presiden AS, Trauman, memproklamasikan penangkapan ikan di laut lepas. Proklamasi tersebut dikeluarkan demi kepentingan melindungi sumber-sumber perikanan dari penangkapan yang destruktif. Presiden Trauman menetapkan pembentukan daerah-daerah perlindungan perikanan (conservation zone) di wilayah laut lepas yang bersambungan dengan pantai AS dan kegiatan menangkap ikan di wilayah itu hanya diperbolehkan bagi warga negara AS. Klaim terbesar setelah proklamasi Trauman dilakukan oleh Chili, Equador, Peru, dan Costa Rica. Pada tahun 1952 negara-negara tersebut menyatakan kedaulatan penuh dan yurisdiksi atas zona sejauh 200 mil dari pantai. ${ }^{23}$ Negara pantai dapat berpartisipasi dalam upaya menjaga ekosistem ikan di laut lepas dengan menentukan kebijakan nasional yang berkaitan.

Masyarakat internasional kemudian berinisiatif untuk membuat peraturan-peraturan hukum internasional tentang perlindungan perikanan di laut. Insiatif tersebut muncul dari kesadaran negara-negara di dunia akan pentingnya upaya untuk melindungi sumber daya ikan di laut. Peraturanperaturan hukum internasional yang terkodifikasi dan disepakati bersama oleh masyarakat internasional merujuk pada kebiasaan-kebiassan negaranegara tertentu dalam upaya melindungi sumber daya ikan di wilayahnya. Perlindungan oleh masyarakat internasional tidak hanya terhadap ikannya semata tetapi lingkungan laut juga penting untuk dijaga kelestariannya. Beberapa peraturan hukum internasional yang dianggap penting untuk melindungi perikanan di laut adalah sebagai berikut:

\footnotetext{
${ }^{22}$ Tjondro Tirtamulia, Zona-Zona Laut UNCLOS, (Surabaya: Brilian Internasional, 2011), hlm. 72.

${ }^{23}$ Op. Cit., Marhaeni Ria Siombo, hlm. 122.
} 


\section{a. United Nations Convention on The Law of Sea (UNCLOS) 1982}

Instrumen-instrumen hukum internasional terkait dengan pengelolaan perikanan tersebut di atas, kiranya perlu terlebih dahulu merujuk pada awal perkembangan hukum laut modern. Hugo Grotius (1583-1645) telah meletakkan prinsip Mare Liberum (freedom of the seas) yang menyatakan bahwa setiap negara bebas menggunakan laut, termasuk sebagai jalur perdagangan. Prinsip tersebut memperoleh perlawanan dari John Selden (1584-1654), yang berpendapat bahwa laut dapat menjadi dominion dan property dari suatu negara seperti halnya darat, atau yang dikenal dengan prinsip Mare Clausum. Dalam perkembangannya kemudian, konsep kebebasan di laut ini lebih mendapat tempat sebagai hukum kebiasaan internasional di bidang hukum laut. ${ }^{24}$

Pasca Perang Dunia II, terdapat kesadaran untuk melakukan pemutakhiran dan kodifikasi hukum kebiasaan internasional. Dengan maksud tersebut maka diadakan Konferensi Hukum Laut I pada 1958 yang kemudian menghasilkan empat Konvensi yang dikenal dengan "Konvensi Jenewa 1958". Konvensi tersebut meliputi the Convention on the Territorial Sea and the Contiguous Zone; the Convention on the High Seas; the Convention on the Continental Shelf; dan the Convention on Fishing and Conservation of the Living Resources of the High Seas. ${ }^{25}$

Dalam perkembangannya, Konvensi Jenewa 1958 mendapat pertentangan keras dari negara-negara pantai. Pada 1970an terdapat ketidakpuasan negara-negara berkembang atas rezim perikanan yang ada, sehubungan dengan fakta bahwa kapal-kapal dari distant developed states, yang dilengkapi dengan teknologi terbaru, melakukan kegiatan penangkapan ikan di laut lepas yang jauh dari pantainya. Pada saat yang sama, beberapa negara maju menyuarakan hal yang sama, terkait dengan keinginan mereka untuk memperoleh akses yang lebih besar atas sumber daya perikanan dan ketidakpercayaan atas kemampuan komisi perikanan internasional untuk mengatur penangkapan ikan di tengah tekanan atas stok ikan akibat semakin intensifnya metode penangkapan ikan. ${ }^{26}$

Dalam Konferensi III Hukum Laut, the Sea Bed Committee mengungkapkan tiga pendekatan terkait dengan perikanan. Pertama, negaranegara berkembang menginginkan yurisdiksi yang luas bagi negara pantai atas perikanan (suatu ide yang kemudian berkembang dalam proposal mengenai Zona Ekonomi Eksklusif/ZEE). Kedua, Amerika Serikat dan Kanada, mengusulkan pendekatan manajemen perikanan berdasarkan

\footnotetext{
${ }^{24}$ William Tetley, International Maritime and Admiralty Law, (International Shipping Publication, Les Editions Yvon Blais Inc, 2002), hlm. 630-631.

${ }^{25} \mathrm{Ibid}$.

${ }^{26}$ Op. Cit., RR Churchill and A.V Lowe, hlm. 288.
} 
karakteristik migrasi spesies yang berbeda, di mana spesies ikan yang bermigrasi jauh akan diatur oleh organisasi perikanan internasional. Ketiga, Jepang dan Uni Soviet memilih status quo, yaitu menginginkan sedikit perubahan dari rezim yang ada, dan berpendapat bahwa negara-negara pantai/berkembang seharusnya menikmati hak-hak preferensial dalam perairan yang dekat dengan pantainya. ${ }^{27}$

Ketentuan-ketentuan dalam UNCLOS 1982 mengenai perikanan memang pada akhirnya merefleksikan pendekatan yang pertama dari negaranegara berkembang, namun demikian elemen-elemen pendekatan spesies dapat pula ditemukan.

UNCLOS 1982 merupakan konvensi internasional yang mengatur hak (right) dan kewajiban (obligation) berbagai negara di dalam melakukan berbagai aktivitas di berbagai zona laut. UNCLOS, 1982 merupakan instrumen hukum internasional yang bersifat mengikat (legally binding instrument). Indonesia telah meratifikasi konvensi internasional ini melalui Undang-Undang Nomor 17 Tahun 1985 tentang Pengesahan United Nations Convention on the Law of the Sea. Beberapa ketentuan UNCLOS, 1982 terkait pengawasan sumber daya perikanan adalah sebagai berikut: ${ }^{28}$

1) Pasal 61 ayat (2) mengatur negara pantai (coastal state) harus melakukan konservasi dan pengelolaan sumber daya hayati di zona ekonomi eksklusif agar tidak rusak karena pemanfaatan yang berlebihan;

2) Pasal 62 ayat (4) menyatakan warga negara lain yang menangkap ikan di zona ekonomi eksklusif harus mematuhi tindakan konservasi, ketentuan dan persyaratan lainnya yang ditetapkan dalam peraturan perundangundangan negara pantai;

3) Pasal 63 ayat (2) mengamanatkan di mana setiap stok ikan yang sama atau setiap stok jenis ikan yang termasuk dalam jenis yang sama yang terdapat baik dalam zona ekonomi eksklusif maupun di luar daerah dan yang berbatasan dengan zona tersebut, maka negara pantai dan negara yang menangkap persediaan jenis ikan demikian di daerah yang berdekatan, harus berusaha baik secara langsung atau melalui organisasi sub-regional atau regional yang bersangkutan untuk mencapai kesepakatan mengenai tindakan yang diperlukan untuk konservasi setiap stok jenis ikan di daerah yang berdekatan tersebut;

4) Pasal 64 ayat (1) menentukan negara pantai dan negara lain yang warga negaranya melakukan penangkapan ikan di kawasan untuk jenis ikan yang berimigrasi jauh, harus bekerja sama secara langsung atau melalui

\footnotetext{
${ }^{27}$ Ibid.

${ }^{28}$ Pandapotan Sianipar, Aspek Legal Instrumen Hukum Internasional Implementasi Pengawasan Sumberdaya Perikanan, http://djpsdkp.kkp.go.id/index.php/arsip/file/137/ aspek-legal-instrumen-hukum-internasional-implementasi-pengawasan-sumberdayaperikanan.pdf/, diakses pada pukul 13.43 WIB, tanggal 11 Juni 2015.
} 
organisasi internasional yang terkait dengan tujuan untuk menjamin konservasi dan meningkatkan tujuan pemanfaatan optimal jenis ikan demikian di seluruh kawasan, baik di dalam maupun di luar zona ekonomi eksklusif;

5) Pasal 73 ayat (1) menyatakan negara pantai dalam melaksanakan hak berdaulatnya untuk melakukan eksplorasi, eksploitasi, konservasi dan pengelolaan sumber daya hayati di zona ekonomi eksklusif dapat mengambil tindakan, termasuk menaiki kapal, inspeksi, menangkap dan melakukan proses peradilan, sebagaimana diperlukan untuk menjamin ditaatinya peraturan perundang-undangan yang ditetapkannya sesuai dengan ketentuan konvensi ini;

6) Pasal 94 ayat (1) mengatur kewajiban negara bendera harus melaksanakan secara efektif yurisdiksi dan pengawasannya dalam bidang administratif, teknis, dan sosial atas kapal yang mengibarkan benderanya;

7) Pasal 117 menyatakan semua negara termasuk negara pantai memunyai kewajiban untuk mengambil tindakan atau kerja sama dengan negara lain dalam mengambil tindakan demikian berkaitan dengan warga negara masing-masing yang dianggap perlu untuk konservasi sumber daya hayati di laut lepas;

8) Pasal 118 mengatur negara-negara harus melakukan kerja sama satu dengan lainnya dalam konservasi dan pengelolaan sumber daya hayati di laut lepas. Negara-negara yang warga negaranya melakukan eksploitasi sumber daya hayati yang sama atau sumber daya hayati yang berlainan di wilayah yang sama, harus mengadakan perundingan dengan tujuan untuk mengambil tindakan yang diperlukan untuk konservasi sumber daya hayati yang bersangkutan. Mereka harus menuntut kebutuhan, bekerja sama untuk menetapkan organisasi perikanan sub-regional atau regional untuk kebutuhan ini; dan

9) Pasal 218 menentukan apabila suatu kendaraan air secara sukarela berada di suatu pelabuhan atau berada pada suatu terminal lepas pantai suatu negara, maka negara pelabuhan (port states) tersebut dapat mengadakan inspeksi. Jika terdapat bukti-bukti yang cukup kuat, mengadakan penuntutan berkenaan dengan setiap pelepasan dari kenderaan air tersebut di luar perairan pedalaman, laut teritorial atau zona ekonomi eksklusif dari negara yang melanggar ketentuan-ketentuan dan standar-standar internasional yang berlaku dan ditentukan melalui organisasi-organisasi internasional yang kompeten atau konferensi diplomatik yang umum.

Pembahasan tentang kerja sama pengelolaan dan konservasi sumber daya perikanan dalam UNCLOS 1982 diatur dalam Bab V tentang Zona Ekonomi Eksklusif (ZEE) khususnya Pasal 61 sampai dengan Pasal 67. Pasal 61 ayat 2 UNCLOS secara jelas mengamanatkan adanya kerja sama di antara negara pantai dan organisasi internasional untuk melakukan tindakan 
pengelolaan dan konservasi perikanan berdasarkan bukti ilmiah yang terbaik (best scientific evidence). Lebih lanjut Pasal 63 dan Pasal 64 UNCLOS memberikan pengaturan tentang stok jenis ikan yang terdapat terdapat di zona ekonomi eksklusif dua negara pantai atau lebih atau baik di dalam zona ekonomi eksklusif maupun di dalam suatu daerah di luar serta berdekatan dengannya, dan jenis ikan yang bermigrasi jauh (highly migratory species). Kedua pasal tersebut menekankan adanya organisasi baik sub-regional, regional, dan global untuk menjamin tindakan yang perlu bagi kegiatan konservasi dan pengelolaan kedua jenis ikan tersebut.

Dalam bagian ini juga diamanatkan kerja sama negara-negara dalam konservasi dan pengelolaan sumber kekayaan hayati di laut lepas sebagaimana yang tertuang pada Pasal 117 dan Pasal 118. Kerja sama yang dimaksud termasuk juga terhadap warga negara masing-masing negara untuk juga melakukan tindakan pengawasan dan pengelolaan sumber kekayaan hayati di laut lepas. Diharapkan ada perundingan antar warga negara dari masing-masing negara yang melakukan tindakan eksploitasi sumber daya hayati di laut lepas.

\section{b. Agreement to Promote Compliance with International Conservation and Management Measures by Fishing Vessels on the High Seas (FAO Compliance Agreement) 1993}

Persetujuan ini berlaku untuk semua kapal perikanan dengan maksud untuk meningkatkan penaatan kapal-kapal perikanan terhadap ketentuanketentuan konservasi sumber-sumber perikanan di laut lepas terutama berkaitan dengan praktik pembenderaan atau pembenderaan semua kapalkapal penangkap ikan. Latar berlakang dibuatnya persetujuan ini adalah adanya kekhawatiran terhadap pengurangan ikan di laut lepas akibat dari peningkatan IUU. Secara khusus persetujuan ini mencoba mengatasi masalah reflagging dan flag of convenience terkait dengan kapal-kapal yang melakukan IUU fishing. ${ }^{29}$

Perjanjian ini ditujukan kepada negara bendera (flag states) dan dilatarbelakangi oleh penurunan stok sumber daya perikanan di laut lepas dan banyaknya kapal perikanan flag of convenience (FOC) yang beroperasi di laut lepas untuk melemahkan efektifitas konservasi dan pengelolaan perikanan di laut lepas. Perjanjian ini merupakan instrumen hukum internasional yang bersifat mengikat (legally binding instrument). Indonesia

\footnotetext{
${ }^{29}$ Melda Kamil Ariadno, Kepentingan Indonesia Dalam Pengelolaan Perikanan Laut Bebas, dalam Jurnal Hukum Internasional (Indonesian Jurnal of International Law), Volume 2 Nomor 3 (Jakarta: Lembaga Pengkajian Hukum Internasional Fakultas Hukum Universitas Indonesia, April 2005), hlm. 513.
} 
sedang memproses ratifikasi perjanjian ini. Beberapa ketentuan perjanjian ini terkait dengan pengawasan sumberdaya perikanan adalah sebagai berikut: ${ }^{30}$

1) Pasal III ayat (1) poin a menyatakan bahwa tanggung jawab negara bendera (flag states) untuk mengambil langkah penting untuk menjamin kapal penangkap ikan yang ditentukan mengibarkan benderanya tidak terlibat aktivitas yang melemahkan efektifitas langkah konservasi dan pengelolaan internasional;

2) Pasal III ayat (7) mengatur agar setiap pihak akan menjamin kapal penangkap ikan yang ditentukan mengibarkan benderanya akan menyediakan informasi tentang operasinya ketika diperlukan untuk memampukan pihak tersebut memenuhi kewajibannya di bawah perjanjian ini, termasuk informasi khusus terkait dengan area operasi penangkapan ikannya, tangkapan, dan pendaratannya;

3) Pasal III ayat (8) menentukan setiap pihak akan mengambil langkah penegakkan terkait kapal penangkap ikan yang mengibarkan benderanya yang mana bertindak bertentangan dengan ketentuan perjanjian ini, termasuk, ketika tepat, melakukan pelanggaran ketentuan demikian di bawah peraturan perundang-undangan nasional. Sanksi yang berlaku terkait dengan pelanggaran demikian harus memberi efek yang cukup efektif dalam menjaga kepatuhan pada kebutuhan perjanjian ini dan membuat efek jera terhadap pelanggar yang memperoleh keuntungan dari aktivitas ilegal mereka;

4) Pasal V ayat (1) menyatakan semua pihak harus bekerja sama ketika perlu di dalam implementasi perjanjian ini, dan akan, secara khusus, bertukar informasi, termasuk materi bukti, sehubungan dengan aktivitas kapal penangkap ikan untuk membantu negara bendera mengidentifikasi kapal penangkap ikan yang mengibarkan benderanya yang dilaporkan terlibat dalam aktivitas yang melemahkan langkah konservasi dan pengelolaan internasional;

5) Pasal $\mathrm{V}$ ayat (2) juga mengatur ketika kapal penangkap ikan secara sukarela berada di pelabuhan dari suatu pihak yang bukan negara bendera, pihak tersebut, di mana memiliki alasan yang masuk akal untuk mempercayai bahwa kapal penangkap ikan tersebut telah melakukan aktivitas yang melemahkan efektifitas langkah konservasi dan pengelolaan internasional, akan segera memberitahu negara bendera terkait. Negara pihak dapat membuat kesepakatan terkait perlakuan oleh negara pelabuhan tentang langkah penyidikan demikian ketika dibutuhkan untuk menentukan apakah kapal penangkap ikan telah benar melanggar ketentuan perjanjian ini; dan

\footnotetext{
${ }^{30}$ Op. Cit., Pandapotan Sianipar, hlm. 3.
} 
6) ketentuan sistem pemantauan kapal (vessel monitoring system/VMS) telah dicantumkan pada lampiran untuk mendukung konservasi dan pengelolaan sumber daya perikanan di laut lepas.

Negara bendera atau setiap pihak dapat melakukan tindakan yang berkaitan dengan perlindungan sumber daya hayati di laut lepas sebagaimana telah diatur dalam Pasal III ayat (1), (7), (8) FAO Compliance Agreement 1993. Pasal III ayat (8) bahkan memberikan kewenangan kepada setiap pihak yang mengetahui ada kapal berbendera yang melakukan penangkapan ikan secara berlebihan dan tidak sesuai dengan perjanjian ini. Sanksi yang diberikan dapat menjadi cara yang efektif untuk menjaga sumber daya hayati di laut lepas. Negara-negara pihak harus melakukan kerja sama untuk mencegah terjadinya pelemahan upaya konservasi dan pengelolaan sumber daya perikanan di laut lepas berdasarkan ketentuan Pasal V ayat (1).

Tujuan ditetapkannya FAO Compliance Agreement 1993 ini adalah untuk meletakkan dasar-dasar praktik penangkapan ikan di laut lepas dan menerapkan langkah-langkah konservasi sumber daya hayati laut dengan meningkatkan peranan organisasi perikanan multilateral. Tujuan lainnya adalah untuk pembuatan database otorisasi kapal perikanan yang ada di laut lepas dan tukar menukar informasi. Aturan mengenai pentingnya kerja sama internasional dalam pengelolaan perikanan tertuang pada Pasal 5, bahwa semua pihak diizinkan apabila diperlukan membuat persetujuan bersama atau persetujuan kerja sama menguntungkan secara global, regional, subregional atau bilateral basis yang bertujuan untuk meningkatkan hasil dari persetujuan ini. Selain itu, diatur juga mengenai kerja sama dengan negara berkembang sebagaimana yang tertuang pada Pasal 8 yang menyebutkan bahwa, "semua pihak akan bekerja sama secara global, regional, subregional atau pada tingkat yang melibatkan dua belah pihak dengan dukungan FAO dan organisasi regional atau internasional lain sebagai penyedia bantuan, termasuk bantuan teknis kepada pihak negara berkembang dalam rangka membantu pelaksanaan kewajiban mereka sesuai persetujuan ini”.

Persetujuan ini berlaku untuk semua kapal perikanan dengan maksud untuk meningkatkan penaatan kapal-kapal perikanan terhadap ketentuanketentuan konservasi sumber-sumber perikanan di Laut Lepas terutama berkaitan dengan praktik pembenderaan atau pembenderaan semua kapalkapal penangkap ikan. Latar berlakang dibuatnya persetujuan ini adalah adanya kekhawatiran terhadap pengurangan ikan di laut lepas akibat dari peningkatan IUU. Secara khusus persetujuan ini mencoba mengatasi masalah reflagging dan flag of convenience terkait dengan kapal-kapal yang melakukan IUU fishing. ${ }^{31}$

\footnotetext{
${ }^{31}$ Op. Cit., Melda Kamil Ariadno, hlm. 513.
} 


\section{c. Agreement for the Implementation of the United Nations Convention} on The Law of The Sea of 10 December 1982 Relating to The Convention and Management of Stadding Fish Stocks and Highly Migratory Fish Stocks (UN Fish Stocks Agreement) 1995

Pengaturan dalam UNCLOS berkaitan dengan pengelolaan dan konservasi sumber daya perikanan tidak mengatur secara rinci tentang hak dan kewajiban negara yang memanfaatkan stocks ikan yang beruaya terbatas dan stocks ikan yang beruaya jauh, hal tersebut menimbulkan potensi munculnya sengketa antara negara pantai dengan negara pantai atau antara negara pantai dengan negara penangkap ikan jarak jauh (distant fishing country) mengenai eksploitasi stocks ikan tersebut secara berlebihan. Disisi lain permasalahan yang muncul adalah stocks sumber daya perikanan terutama stocks ikan yang beruaya terbatas dan stocks ikan yang beruaya jauh terus mengalami penurunan secara drastis.

UNCLOS 1982 telah memuat ketentuan mengenai pengaturan pengelolaan sumber daya ikan yang bermigrasi jauh (highly migratory). Namun pengaturan yang termuat pada Pasal 64 UNCLOS 1982 tersebut hanya berlaku di zona ekonomi eksklusif, di mana negara pantai memunyai hak berdaulat secara eksklusif untuk mengeksplorasi, mengeksploitasi, melindungi, dan mengatur perikanan di wilayahnya sejauh 200 mil laut. Dengan demikian, adanya kekosongan aturan tentang persediaan jenis-jenis ikan yang bermigrasi jauh (higly migratory fish stocks/HMFS) serta jenisjenis ikan yang bermigrasi terbatas (straddling fish stock/SFS) laut lepas.

Tanggal 4 Desember tahun 1995 dalam UN Conference on Straddling Fish Stocks and Highly Migratory Fish Stocks sesi ke 6, PBB berhasil mengadopsi suatu persetujuan untuk mengimplementasikan ketentuan tersebut di atas dalam bentuk Agreement for the Implementation of the Provisions of the UNCLOS of 10 Desember 1982 relating to the Conservation and Management of Straddling Fish Stocks and Highly Migratory Fish Stocks (United Nations Fish Stocks Agreement) 1995. Persetujuan tersebut merupakan upaya untuk menumbuhkan kesadaran global akan pentingnya konservasi jenis ikan-ikan yang bermigrasi jauh dan bermigrasi terbatas, serta dalam kerangka mengimplementasikan ketentuanketentuan Konvensi Hukum Laut 1982 yang memiliki keterkaitan dengan jenis ikan-ikan yang telah disebutkan sebelumnya.

Beberapa ketentuan perjanjian ini terkait dengan pengawasan sumber daya perikanan adalah sebagai berikut: ${ }^{32}$

1) Pasal 8 ayat (1) mengatur negara pantai dan negara yang menangkap ikan di laut lepas, sesuai dengan UNCLOS, 1982, melakukan kerja sama terkait dengan stok ikan beruaya terbatas dan stok ikan beruaya jauh baik

\footnotetext{
${ }^{32}$ Op. Cit, Pandapotan Sianipar, hlm. 4
} 
secara langsung atau melalui organisasi atau kerja sama pengelolaan perikanan sub-regional atau regional, sesuai dengan karakteristik spesifik sub-regional atau regional tersebut, untuk memastikan konservasi dan pengelolaan yang efektif stok demikian.

2) Pasal 10 poin $h$ menyatakan negara-negara di dalam memenuhi kewajiban mereka untuk bekerja sama melalui organisasi atau kerjasama pengelolaan perikanan regional, akan membentuk mekanisme kerja sama yang cocok untuk pemantauan (monitoring), pengendalian (control), pengawasan (surveillance), dan penegakan (enforcement).

3) Pasal 18 ayat (2) menentukan negara bendera yang memiliki kapal yang menangkap ikan di laut lepas harus mengambil langkah untuk memastikan kapal yang mengibarkan benderanya patuh pada langkah konservasi dan pengelolaan sumber daya perikanan sub-regional dan regional, sehingga kapal tersebut tidak terlibat aktivitas yang melemahkan efektifitas langkah demikian.

4) Pasal 19 ayat (2) mengatur semua investigasi dan proses peradilan akan dilaksanakan secepatnya. Sanksi yang berlaku sehubungan dengan pelanggaran harus cukup efektif di dalam menjamin kepatuhan dan untuk mencegah pelanggaran di manapun mereka terjadi dan akan memberi efek jera bagi pelanggar yang memperoleh keuntungan dari aktivitas ilegal mereka.

5) Pasal 20 menentukan negara-negara akan bekerja sama, baik secara langsung atau melalui organisasi atau kerja sama pengelolaan perikanan sub-regional dan regional, untuk memastikan kepatuhan pada dan penegakan langkah konservasi dan pengelolaan sub-regional dan regional untuk stok ikan beruaya terbatas dan stok ikan beruaya jauh.

6) Pasal 21 ayat (4) menyatakan sebelum mengambil aksi di bawah pasal ini, negara pengawas (inspecting states) akan, baik secara langsung atau melalui organisasi atau kerja sama pengelolaan perikanan sub-regional atau regional, menginformasikan semua negara yang memiliki kapal penangkap ikan di laut lepas di dalam sub-regional atau regional tersebut form identifikasi yang diterbitkan ke inspektur yang diotorisasi. Kapal yang digunakan untuk boarding dan inspeksi akan ditandai secara jelas dan dapat diidentifikasi sebagai dinas pemerintah.

7) Pasal 21 ayat (5) mengatur, menindaklanjuti boarding dan inspeksi, ada alasan yang masuk akal untuk mempercayai bahwa suatu kapal telah terlibat dalam aktivitas yang bertentangan dengan langkah konservasi dan pengelolaan, negara pengawas (inspecting state) akan, di mana tepat, mengamankan bukti dan akan segera memberitahu kepada negara bendera dinyatakan adanya pelanggaran.

8) Pasal 23 menentukan bahwa negara pelabuhan memiliki hak dan tugas untuk mengambil langkah, sesuai dengan hukum internasional, untuk 
mempromosikan keefektifan langkah konservasi dan pengelolaan subregional, regional, dan global. Ketika mengambil tindakan demikian, negara pelabuhan tidak akan diskriminasi dalam prosedur atau tindakan terhadap kapal semua negara.

Pasal 8 menyebutkan bahwa hanya negara yang menjadi anggota dari organisasi atau pengaturan perikanan sub-regional atau regional, dan bekerja sama dalam penerapan ketentuan konservasi dan pengelolaannya, memiliki hak akses untuk memanfaatkan jenis-jenis ikan yang beruaya terbatas dan jenis-jenis ikan yang beruaya jauh di laut lepas. Lebih jauh, untuk melaksanaan hak akses tersebut, negara yang telah menjadi anggota organisasi perikanan regional disyaratkan untuk menyetujui jumlah tangkapan yang diperbolehkan (Total Allowable Catch /TAC) dan Levels of Fishing Effort, serta telah mempersiapkan mekanisme kerja sama dalam kegiatan Monitoring Control and Surveillance/MCS dan penegakan hukumnya secara efektif.

Bab III Perjanjian ini menyebutkan bahwa, "mekanisme untuk kerja sama internasional dalam pengelolaan jenis-jenis ikan yang bermigrasi jauh dan jenis-jenis ikan yang bermigrasi terbatas, baik secara langsung maupun tidak melalui kesepakatan atau organisasi pengelolaan perikanan regional dan sub-regional". Beberapa tujuan dilakukannya kerja sama adalah agar negara-negara menyepakati untuk melakukan tindakan konservasi dan pengelolaan dalam rangka menghindarkan dari over fishing.

Dalam Pasal 24 UN Fish Stocks Agreement 1995 juga diatur mengenai pengakuan persyaratan-persyaratan khusus untuk negara-negara berkembang termasuk bentuk bentuk kerja sama dengan negara-negara berkembang. Selain itu Bagian VII memberikan secara rinci prosedur penyelesaian sengketa secara damai. Selain itu juga disebutkan bahwa dalam hal batas penerapan prosedur penyelesaian sengketa berlaku ketentuan Pasal 297 ayat 3 UNCLOS 1982.

Satu hal yang menarik dari UN Fish Stocks Agreement 1995 adalah ketentuan mengenai kewenangan dari negara peserta suatu RFMOs melalui inspektur yang berwenang dapat menaiki kapal milik negara peserta maupun negara bukan peserta dari RFMOs untuk memastikan penaatan tindakan dan konservasi yang di tetapkan oleh RFMOs tersebut sebagaimana diatur dalam pasal 21 UN Fish Stocks Agreement. Tindakan tersebut dapat melanggar salah satu prinsip yang dikenal dalam hukum perjanjian internasional yaitu "pacta tertiis nec nocent nec prosunt". Dari sisi kepentingan pembangunan perikanan berkelanjutan hal tersebut memang bisa dibenarkan namun disisi lain ketentuan tersebut akan menimbulkan sengketa. ${ }^{33}$

\footnotetext{
${ }^{33}$ Op. Cit., Boer Mauna, hlm. 143,
} 
UN Fish Stocks Agreement 1995 adalah salah satu kerangka pengaturan perikanan laut lepas yang signifikan, sebagai pengaturan pelaksanaan UNCLOS 1982. Ketentuan UN Fish Stocks Agreement 1995 banyak mengacu pada ketentuan UNCLOS 1982 dan merupakan penjabaran lebih lanjut ketentuan konservasi sumber daya perikanan yang diatur dalam UNCLOS 1982. UN Fish Stocks Agreement mulai berlaku tanggal 11 Januari 2001 ditandantangani oleh 59 negara dan telah diratifikasi oleh 77 negara termasuk Indonesia. Dengan demikian UN Fish Stocks Agreement telah sukses dalam misinya untuk mendukung UNCLOS 1982 dan memberikan koreksi terhadap kelemahan konvensi tersebut yang berkaitan dengan pengelolaan perikanan di laut lepas. ${ }^{34}$

\section{d. FAO Code Conduct For Responsible Fisheries (CCRF) 1995}

CCRF disusun berdasarkan rekomendasi yang muncul dari diskusi dalam Committee on Fisheries (COFI) pada bulan maret 1991. Dalam pertemuan di Cancun, Mexico pada tahun 1992 dihasilkan suatu dekalarasi (Deklarasi Cancun 1992) yang memberikan mandat kepada FAO untuk menyusun suatu perikanan yang betanggung jawab. Dalam deklarasi tersebut terdapat beberapa poin yang merupakan dasar bagi dibentuknya CCRF. ${ }^{35}$ Beberapa ketentuan FAO CCRF, 1995 terkait dengan pengawasan sumber daya perikanan adalah sebagai berikut: ${ }^{36}$

1) Paragraf 8.1.1 mengamanatkan semua negara harus memastikan bahwa hanya operasi penangkapan yang diijinkan oleh mereka dilaksanakan di dalam perairan di bawah yurisdiksi mereka dan operasi tersebut dilakukan dalam cara yang bertanggung jawab;

2) Paragraf 8.1.4 menyatakan bahwa negara-negara harus, sesuai dengan hukum internasional, dalam kerangka kerja organisasi atau kerja sama pengelolaan perikanan regional, bekerja sama untuk membentuk sistem untuk pemantauan (monitoring), pengendalian (control), dan pengawasan (surveillance) dan penegakan (enforcement) langkah yang berlaku terkait dengan operasi penangkapan ikan dan aktivitas yang berkaitan di perairan di luar yurisdiksi nasional mereka;

3) Paragraf 8.2.7 mengatur agar negara bendera harus mengambil langkah penegakan terhadap kapal penangkap ikan yang ditentukan mengibarkan bendera mereka yang telah ditemukan melakukan tindakan yang berlawanan dengan langkah konservasi dan pengelolaan yang berlaku,

\footnotetext{
${ }^{34}$ Op.Cit, Melda Kamil Ariadno, hlm. 511

${ }^{35}$ Lucky Andrianto, Implementasi Code of Conduct For Responsible Fisheries dalamPerspektif Negara Berkembang, Jurnal Hukum Internasional (Indonesian Jurnal ofInternational Law), Volume 2 Nomor 3, (Jakarta: Lembaga Pengkajian Hukum InternasionalFakultas Hukum Universitas Indonesia, April 2005), hlm. 473

${ }^{36}$ Op. Cit, Pandapotan Sianipar, hlm. 5
} 
jika perlu termasuk menganggap ketidakpatuhan tersebut sebagai suatu pelanggaran menurut peraturan perundang-undangan nasional;

4) Paragraf 8.3.1 mengamanatkan negara pelabuhan harus mengambil, melalui prosedur yang ditentukan dalam peraturan perundang-undangan nasional mereka, sesuai dengan hukum internasional, termasuk perjanjian atau kerja sama internasional yang berlaku, langkah demikian ketika perlu untuk mencapai dan membantu negara lain di dalam mencapai tujuan kode ini, dan harus memberitahu negara lain perincian regulasi dan langkah yang telah mereka tentukan untuk tujuan ini. Ketika mengambil langkah demikian negara pelabuhan harus tidak diskriminasi dalam prosedur atau tindakan terhadap kapal-kapal negara lain;

5) Paragraf 8.3.2 menyatakan bahwa negara pelabuhan harus menyediakan bantuan kepada negara bendera jika perlu, sesuai dengan hukum nasional negara pelabuhan dan hukum internasional, ketika kapal penangkap ikan sukarela di pelabuhan atau di terminal lepas pantai negara pelabuhan dan negara bendera kapal tersebut meminta bantuan negara pelabuhan terkait ketidakpatuhan pada langkah konservasi dan pengelolaan sub-regional, regional atau global atau dengan standar minimum yang disetujui secara internasional untuk pencegahan, dari pencemaran dan untuk keselamatan, kesehatan serta kondisi kerja di atas kapal penangkap ikan; dan

6) Paragraf 11.1.11 menentukan negara harus memastikan perdagangan ikan dan produk perikanan internasional dan domestik sesuai dengan praktik konservasi dan pengelolaan yang layak melalui peningkatan identifikasi asal ikan dan produk perikanan yang diperdagangkan.

CCRF 1995 merupakan buku petunjuk yang sangat penting bagi seluruh masyarakat perikanan, baik nasional maupun internasional untuk menjamin kegiatan perikanan yang berkelanjutan dan bertanggung jawab di wilayah pesisir dan laut. Berdasarkan Pasal 12 bahwa menyepakati standarstandar untuk efektivitas pengelolaan dan konservasi sumber daya laut serta perikanan bertanggung jawab. CCRF merupakan tempat terbaik RFMO dalam melaksanakan pengelolaan, meskipun pelaksanaan CCRF bersifat sukarela. adalah: ${ }^{37}$

Asas umum dari Code of Conduct for Responsible Fisheries (CCRF)

1) negara-negara dan pengguna sumber daya hayati akuatik harus melakukan konservasi ekosistem akuatik terutama dalam hal menangkap ikan dan wajib melakukan konservasi dengan cara yang bertanggung jawab;

2) pengelolaan harus menjamin mutu, keanekaragaman, dan ketersediaan sumber daya perikanan untuk generasi kini dan yang akan datang;

\footnotetext{
${ }^{37}$ Op. Cit, Marhaeni Ria Siombo, hlm. 65.
} 
3) negara-negara harus mencegah penangkapan ikan yang melebihi kapasitas, dan menjamin penangkapan yang seimbang dan pemanfaatan yang lestari;

4) negara harus memberikan prioritas kepada peneliti dalam meningkatkan pengetahuan ilmiah, teknis perikanan dan interaksinya dengan ekosistem serta mendorong kerja sama bilateral dan multilateral; dan

5) negara harus memperlakukan pendekatan kehati-hatian terhadap konservasi, pengelolaan dan pemanfaatan sumber daya ikan.

\section{e. FAO International Plan of Action for Illegal, Unreported, and Unregulated, Fishing}

Illegal, unreported, and unregulated (IUU) fishing merupakan kegiatan penangkapan ikan illegal, tidak dilaporkan (unreported), dan tidak diregulasi (unregulated) di laut lepas atau perairan yurisdiksi negara pantai. IUU fishing merusak sumber daya kelautan dan perikanan, sehingga melemahkan efektifitas konservasi dan pengelolaan sumber daya perikanan. Semua negara harus mendukung pemberantasan IUU fishing. FAO IPOAIUU Fishing, 2001 merupakan instrumen hukum internasional yang bersifat sukarela (voluntary instrument) dan mengatur tanggung jawab (responsible) berbagai negara dalam pemberantasan IUU fishing. Beberapa ketentuan FAO IPOA-IUU Fishing, 2001 terkait dengan pengawasan sumber daya perikanan adalah sebagai berikut: ${ }^{38}$

1) Paragraf 10 menyatakan semua negara harus memberi efek penuh terhadap norma hukum internasional yang terkait, khususnya yang ditunjukkan dalam UNCLOS, 1982, untuk mencegah (preventing), menghalangi (detering) dan mengeliminasi (eliminating) IUU fishing;

2) Paragraf 21 mengatur agar semua negara harus menjamin bahwa sanksi untuk kapal IUU fishing dan, memberikan sebesar mungkin bagi warganya di bawah yurisdiksinya sanksi yang cukup efektif untuk mencegah, menghalangi dan mengeliminasi IUU fishing secara efektif dan menghindarkan pelanggar dari keuntungan yang diperoleh dari penangkapan ikan demikian. Hal ini mungkin termasuk menerapkan rezim sanksi sipil berdasarkan pada skema sanksi administratif. Negara harus menjamin penerapan sanksi secara transparan dan konsisten;

3) Paragraf 24 mengamanatkan bahwa negara-negara harus melakukan pemantauan (monitoring), pengendalian (control), dan pengawasan (surveillance) yang komprehensif dan efektif, dari mulai keberangkatan, melalui titik pendaratan, sampai ke tujuan akhir;

4) Paragraf 25 mengatur negara-negara harus mengembangkan dan mengimplementasikan, sesegera mungkin tetapi tidak lebih lambat dari 3

${ }^{38}$ Ibid. 
tahun setelah adopsi IPOA, rencana aksi nasional (national plan of action) untuk lebih lanjut mencapai tujuan IPOA dan memberi efek yang penuh ke ketentuannya sebagai bagian terpadu dari program pengelolaan perikanan dan anggaran mereka;

5) Paragraf 28 menyatakan bahwa negara harus berkoordinasi dan bekerja sama dalam aktivitas mereka secara langsung, dan ketika tepat melalui organisasi pengelolaan perikanan regional yang terkait, di dalam mencegah, menghalangi, dan mengeliminasi IUU fishing;

6) Paragraf 34 menentukan agar negara bendera harus menjamin bahwa kapal penangkap ikan yang ditentukan mengibarkan bendera mereka tidak terlibat dalam atau mendukung IUU fishing;

7) Paragraf 51 menyatakan di dalam menegakkan hak kedaulatan negara pantai untuk mengeksplorasi dan mengeksploitasi, melakukan konservasi, dan mengelola sumber daya hayati laut di bawah jurisdiksi mereka, di dalam kepatuhan pada UNCLOS 1982 dan hukum internasional, setiap negara pantai harus mengimplementasikan langkah untuk mencegah, menghalangi, dan mengeliminasi IUU fishing di zona ekonomi eksklusif. Di antara langkah yang mana negara pantai harus mempertimbangkan, konsisten dengan peraturan perundang-undangan nasional dan hukum internasional;

8) Paragraf 55 mengatur agar sebelum mengijinkan kapal akses pelabuhan, negara pelabuhan harus meminta kapal penangkap ikan dan kapal yang terlibat dalam aktivitas terkait penangkapan ikan yang meminta ijin masuk ke pelabuhan mereka memberikan pemberitahuan alasan yang masuk akal masuknya mereka ke pelabuhan, salinan ijin untuk menangkap ikan mereka, perincian perjalanan penangkapan ikan mereka dan jumlah ikan di atas kapal, dengan memperhatikan kebutuhan kerahasian, untuk menentukan apakah kapal tersebut mungkin telah terlibat dalam, atau mendukung IUU fishing;

9) Paragraf 56 menyatakan bahwa ketika negara pelabuhan memiliki bukti yang jelas bahwa suatu kapal yang telah diberi akses ke pelabuhannya telah terlibat dalam aktivitas IUU fishing, negara pelabuhan harus tidak mengijinkan kapal tersebut mendaratkan atau memindahkan ikan di dalam pelabuhannya, dan harus melaporkan masalah tersebut ke negara bendera kapal tersebut;

10) Paragraf 66 menentukan bahwa negara mengambil semua langkah yang penting, konsisten dengan hukum internasional, untuk mencegah ikan yang ditangkap oleh kapal yang teridentifikasi oleh organisasi pengelolaan perikanan regional telah terlibat dalam IUU fishing sedang diperdagangkan atau diimpor ke dalam wilayah mereka. Identifikasi kapal tersebut oleh organisasi pengelolaan perikanan regional harus dibuat melalui prosedur yang disetujui dalam cara yang fair, transparan, 
dan tidak diskrimanasi. Langkah sehubungan perdagangan harus diadopsi dan diimplementasikan sesuai dengan hukum internasional, termasuk prinsip, hak dan kewajiban yang ditentukan dalam Perjanjian WTO, dan diimplementasikan dalam cara yang fair, transparan dan tidak diskriminasi; dan

11) Paragraf 69 mengatur bahwa langkah terkait perdagangan untuk mengurangi atau membatasi perdagangan ikan dan produk perikanan yang diperoleh dari IUU fishing dapat termasuk adopsi kebutuhan dokumentasi dan sertifikasi tangkapan multilateral, di samping langkah multilateral terkait lain yang tepat seperti kontrol atau pelarangan impor dan ekspor. Langkah demikian harus diadopsi dalam cara yang fair, transparan dan tidak diskriminasi. Ketika langkah demikian diadopsi, negara harus mendukung implementasinya yang konsisten dan efektif.

\section{Kedudukan Indonesia dalam Upaya Konservasi Stok Ikan di Laut Lepas}

Kedudukan Indonesia dalam hal ini adalah status sebagai negara kepulauan membuat Indonesia harus berperan penting dalam tindakan konservasi sumber daya ikan di laut. Peranan sektor perikanan bagi bangsa Indonesia juga sangat besar. Indonesia adalah negara kepulauan, dengan $2 / 3$ (dua pertiga) wilayahnya berupa laut. Lebih dari $60 \%$ masyarakat Indonesia hidup di wilayah pesisir dengan mata pencaharian dari laut. Mereka bukan saja para nelayan atau para pembudi daya ikan, tetapi juga yang berhubungan tidak langsung dengan laut seperti pedagang atau jasa-jasa lainnya. Pada wilayah pesisir dan pantai tersebut terdapat lebih dari 100 juta penduduk Indonesia bermukim. ${ }^{39}$

Perairan Indonesia dan ZEE Indonesia (Samudera Hindia dan Samudera Pasifik) merupakan lintasan ikan-ikan yang beruaya jauh yang termasuk ke dalam kelompok tuna besar (large tuna) dan paruh panjang (bill fish)..$^{40}$ Kelompok tuna besar adalah :

a. Madidihang/ Yellowfin/ Thunus Albacares;

b. Mata Besar/ Big Eyel Thunus Obesus;

c. Albacaro/ Albacorel Thunus Alalunga;

d. Tuna Sirip Biru Selatan/ Southern Bluefin Tunal Thunus Tonggol; dan

e. Cakalang/ Skipjack/Katsowonnus Pelamis.

Kelompok paruh panjang adalah:

a. Ikan Layaran/ Sail Fish/ Istiophonus Platypterus;

b. Ikan Pedang/Swordfish/ Xiphias Gladius;

\footnotetext{
${ }^{39} \mathrm{Op}$. Cit., Hari Yulianto, hlm. 13.

${ }^{40}$ Op. Cit., Marhaeni Ria Siombo, hlm 85.
} 
c. Satuhuk/Marlin/ Makaira Spp; dan

d. Setuhuk Loreng/ Stripped Marlin/ Terapturus Audaxs.

Wilayah nusantara juga merupakan daerah yang cocok bagi kegiatan pemijahan ikan, salah satunya berada pada wilayah perairan ZEE Indonesia yaitu pada perairan selatan Jawa dan Bali $\left(8^{\circ} \mathrm{LS}-50^{\circ} \mathrm{LS}\right)$, di mana ikan tuna sirip biru melakukan pemijahan pada bulan September-April. Secara geografis, wilayah Indonesia merupakan wilayah kepulauan terbesar dan teragam di dunia dengan lebih dari 17.000 pulau dan memiliki garis pantai sepanjang $95.181 \mathrm{~km}$. Samudera Hindia dan Samudera Pasifik, yang mengapit wilayah Indonesia, juga membawa pengaruh bagi biodiversity laut terluas di dunia dan terumbu karang yang menopang berlimpahnya sediaan ikan yang beragam. ${ }^{41}$

Bentuk kepedulian dan kepentingan Indonesia terhadap laut sangat signifikan, karena Indonesia merupakan negara kepulauan yang begitu besar. Hal tersebut dapat dilihat dari keikutsertaan Indonesia dalam beberapa persetujuan instrumen hukum internasional. UNCLOS, 1982 merupakan konvensi internasional yang mengatur hak (right) dan kewajiban (obligation) berbagai negara di dalam melakukan berbagai aktivitas di berbagai zona laut. UNCLOS, 1982 merupakan instrumen hukum internasional yang bersifat mengikat (legally binding instrument). Indonesia telah meratifikasi konvensi internasional ini melalui Undang-Undang Nomor 17 Tahun 1985 tentang Pengesahan United Nations Convention on the Law of the Sea.

Usaha negara Indonesia dalam menjaga dan melindungi stok sumber daya ikan di laut lepas dapat dilihat dari Indonesia telah meratifikasi perjanjian ini melalui Undang-Undang Nomor 21 Tahun 2009 tentang Pengesahan Agreement for The Implementation of The Provisions of The United Nations Convention on The Law of The Sea of 10 Desember 1982 Relating to The Conservation and Management of Straddling Fish Stocks and Highly Migratory Fish Stocks. Perjanjian ini ditujukan kepada negara pantai (coastal states) dan negara bendera (flag states). Perjanjian ini dilatarbelakangi oleh penurunan stok ikan beruaya terbatas (straddling migratory fish stock) dan stok ikan beruaya jauh (highly migratory fish stocks) di laut lepas dan zona ekonomi eksklusif negara pantai. Perjanjian ini merupakan instrumen hukum internasional yang bersifat mengikat (legally binding instrument).

Indonesia juga telah mengadopsi ketentuan-ketentuan CCRF dalam peraturan perundang-undangan dalam bidang perikanan. Di Indonesia pengaturan tentang pengelolaan dan konservasi sumber daya perikanan di zona ekonomi ekslusif dan laut lepas diatur dalam Undang-Undang Nomor 31 Tahun 2004 tentang Perikanan yang merupakan Undang-Undang

${ }^{41}$ Ibid. 
pengganti Undang-Undang Nomor 9 tahun 1985. Salah satu alasan strategis diadakannya perubahan Undang-Undang Nomor 9 tahun 1985 adalah adanya perkembangan objektif mengenai IPTEK, tata ruang, perkembangan sosial ekonomi regional dan lokal, serta tuntutan internasional memerlukan pengaturan yang jelas di bidang perikanan.

Undang-Undang Nomor 31 Tahun 2004 dan Undang Nomor 45 Tahun 2009 merupakan cerminan politik hukum Indonesia untuk menjadi anggota dari Regional Fisheries Management Organization (RFMOs) dan ikut serta dalam pengelolaan dan konservasi sumber daya perikanan di laut lepas hal tersebut tercermin dalam Pasal 10 ayat (2) yang secara tegas menyatakan bahwa pemerintah ikut serta secara aktif dalam keanggotaan badan/lembaga/organisasi regional dan internasional dalam rangka kerja sama pengelolaan perikanan regional dan internasional.

Berdasarkan ketentuan hukum internasional, konservasi dan pengelolaan jenis-jenis ikan yang beruaya terbatas maupun jenis-jenis yang bermigrasi jauh dimandatkan untuk diatur lebih lanjut dalam RFMOs. Pada saat ini telah berdiri beberapa RFMOs yang berada di sekitar Indonesia, antara lain Komisi Tuna Samudera Hindia (India Ocean and Tuna Commision/IOTC), Komisi Perikanan Untuk Pasifik Barat dan Tengah (Western and Central Pasific Fisheries Commision/WCPFC), dan Konvensi tentang Konservasi Tuna Sirip Biru (Convention on The Conservation of Southern Bluefin Tuna/CCSBT). ${ }^{42}$

Sejumlah inisiatif telah diambil Indonesia, diantaranya dengan mengadopsi sejumlah ketentuan internasional yang diharapkan dapat memperbaiki situasi pengelolaan dan pelestarian perikanan nasional. Saat ini, Indonesia telah menjadi pihak pada dua RFMO yang ada, yaitu Indian Ocean Tuna Commission (IOTC) dan Commission for the Conservation of Southern Blufin Tuna (CCSBT), serta menjadi cooperating non-members pada Commission for the Conservation and Management of Highly Migratory Fish Stocks in the Western and Central Pacific Ocean (WCPFC). ${ }^{43}$ Keputusan Presiden Nomor 109 Tahun 2007 tentang Pengesahan Convention for the Conservation of Southern Bluefin Tuna, maka pelarangan impor tersebut telah berhasil dibuka kembali mulai tahun 2007.

Peran Indonesia dapat dilihat dari keikutsertaan organisasi internasional maupun regional serta meratifikasi beberapa peraturan internasional yang berkaitan dengan konservasi sumber daya ikan di laut. Indonesia juga telah memiliki beberapa peraturan perundang-undangan yang

\footnotetext{
${ }^{42}$ Op. Cit., Marhaeni Ria Siombo, hlm. 86.

${ }^{43}$ Op. Cit., Hari Yulianto, hlm. 14.
} 
mengatur tentang perlindungan sumber daya ikan di laut, khususnya perlindungan ikan di laut lepas.

\section{a. Undang-Undang Nomor 45 Tahun 2009 tentang Perikanan}

Undang-Undang Nomor 45 Tahun 2009 tentang Perikanan merupakan Undang-Undang (UU) pengganti UU No. 31 Tahun 2004 tentang Perikanan. Perubahan tersebut meliputi beberapa aspek penting yang masih dianggap lemah yaitu masalah penegakan hukum dan pengawasan, masalah pengelolaan perikanan termasuk konservasi dan perizinan. ${ }^{44}$ Perubahan beberapa aspek dalam UU tersebut sebagai sebuah upaya untuk mengatasi isu-isu dalam pembangunan perikanan yang perlu mendapatkan perhatian dari semua pihak baik masyarakat, swasta dan pemerintah maupun pihak lain yang berkaitan dengan pengelolaan sumber daya ikan.

UU ini mengatur beberapa poin yang berkaitan dengan konservasi sumber daya ikan. Konsep konservasi sumber daya ikan di dalam UU ini adalah upaya perlindungan, pelestarian, dan pemanfaatan sumber daya ikan, termasuk ekosistem, jenis dan genetik untuk menjamin keberadaan, ketersediaan, dan kesinambungannya dengan tetap memelihara dan meningkatkan kualitas nilai dan keanakaragaman sumber daya ikan. ${ }^{45}$ Penjelasan tentang konsep konservasi dalam UU tersebut tidak memfokuskan pada wilayah tertentu, sehingga dapat disimpulkan bahwa konservasi dalam UU ini meliputi perairan laut lepas.

Ketentuan-ketentuan dalam UU ini yang mengatur tentang upaya konservasi sumber daya ikan di laut lepas. Pasal 27 angaka 1 mengatur tentang kewajiban bagi setiap orang yang mengoprasikan kapal penangkap ikan berbendera Indonesia di wilayah peraiaran Negara Republik Indonesia dan/atau di laut lepas wajib memiliki Surat Izin Penangkapan Ikan (SIPI). Pasal 36 kewajiban bagi setiap kapal perikanan milik orang Indonesia yang dioperasikan di laut lepas wajib didaftarkan terlebih dahulu sebagai kapal perikanan Indonesia. Jika kapal yang dioprasikan menangkap ikan di laut lepas tanpa SIPI, maka dapat dipidana dengan pidana penjara paling lama 6 (enam) tahun dan denda paling banyak Rp.2.000.000.000,- (dua miliar rupiah) ${ }^{46}$

Pengaturan konservasi sumber daya ikan di laut lepas masih sangat lemah di dalam UU ini. UU ini tidak mengatur tentang pembatasan penangkapan ikan oleh kapal penangkap ikan di laut lepas, sehingga hal dapat menyebabkan over fishing di laut lepas. UU ini juga tidak mengatur kapal perikanan milik orang asing yang melakukan pelanggaran

\footnotetext{
${ }^{44}$ Undang-Undang Nomor 45 Tahun 2009 tentang Perikanan.

${ }^{45}$ Pasal 1 angka 8 Undang-Undang Nomor 45 Tahun 2009 tentang Perikanan.

${ }^{46}$ Pasal 93 Undang-Undang Nomor 45 Tahun 2009 tentang Perikanan.
} 
penangkapan ikan di laut lepas. Berdasarkan Pasal 117 dan 118 UNCLOS 1982 bahwa negara pantai dapat mengambil tindakan pengawasan dan pengelolaan sumber kekayaan hayati di laut lepas. UN Fish Stocks Agreement 1995 juga memiliki ketentuan mengenai kewenagan negara peserta untuk mengambil tindakan terhadap kapal peserta atau bukan peserta yang melakukan pelanggaran penangkapan ikan. Indonesia merupakan peserta peratifikasi Agreement tersebut.

UU ini juga tidak mencantumkan jenis ikan yang harus dilindungi di laut lepas. UN Fish Stocks Agreement 1995 menjelaskan bahwa jenis ikan yang harus dilindungi di laut lepas adalah ikan beruaya jauh dan ikan beruaya terbatas.

\section{b. Peraturan Menteri Kelautan dan Perikanan Republik Indonesia No. PER.03/MEN/2009 tentang Penangkapan Ikan dan/atau Pengangkutan Ikan}

Peraturan Menteri ini merupakan bagian dari tindak lanjut pemerintah setelah Indonesia bergabung dengan menjadi anggota pada beberapa organisasi pengelolaan perikanan regional. Peraturan ini secara khusus mengatur tentang hal-hal yang berkaitan dengan penangkapan ikan dan/atau pengangkutan ikan oleh orang atau badan hukum Indonesia dan/atau kapal perikanan berbendera Indonesia di laut lepas. Dalam Peraturan Menteri ini diatur mengenai perizinan penangkapan ikan di laut lepas dan juga hak dan kewajiban bagi setiap orang atau badan hukum Indonesia, kapal penangkap ikan dan kapala pengangkut ikan yang melakukan kegiatan penangkapan ikan di laut lepas dan/atau pengangkutan ikan di laut lepas.

Beberapa poin dalam peraturan ini telah disesuaikan dengan peraturan internasional yang telah diratifikasi oleh Indonesia. Poin-poin yang dimaksud dan belum diatur dalam peraturan perundang-undangan sebelumnya yaitu sebagai berikut:

1) bahwa setiap kapal penangkap dan pengangkut ikan berbendera Indonesia harus terdaftar pada organisasi pengelola perikanan regional; dan

2) bahwa peraturan ini juga mengharuskan kapal penangkap dan pengangkut ikan berbendera asing memperoleh izin dari kepala pelabuhan setempat yang ada di Indonesia.

Poin-poin di atas dianggap penting dalam upaya konservasi sumber daya ikan di laut lepas. Seperti yang telah di bahas di atas bahwa dalam UU No. 45 Tahun 2009 tentang Perikanan belum mengatur kedua poin di atas. Salah satu yang menarik untuk diperhatikan adalah diaturnya definisi pengertian tentang RFMOs yang lebih sederhana dari yang diatur dalam CCRF dan hanya terbatas pada kegiatan pengelolaan perikanan di laut lepas. Seluruh hak dan kewajiban yang diatur dalam Peraturan Menteri ini telah sesuai dengan pengaturan internasional tentang pengelolaan dan konservasi 
sumber daya perikanan yang ada. Akan tetapi, Peraturan Menteri ini juga belum dianggap cukup untuk menjaga konservasi sumber daya ikan di laut lepas karena masih ada beberapa kelemahan. Bentuknya yang hanya sebatas Peraturan Menteri menyebabkan keberlakuannya tidak begitu efektif.

Peraturan Menteri ini tidak menyebutkan pembatasan ikan yang boleh ditangkap di laut lepas. Selain itu, peraturan ini juga belum menyebutkan jenis ikan yang tidak boleh ditangkap. Sedangkan untuk sanki, peraturan ini hanya bisa memberikan sanksi administratif terhadap pelaku pelanggaran di laut lepas.

\section{c. Peraturan Menteri Nomor Per.12/Men/2012 tentang Usaha Perikan Tangkapdi Laut Lepas}

Setalah pengesahan peraturan menteri di atas, kemudian dibuat juga Peraturan Menteri Nomor Per.12/Men/2012 tentang Usaha Perikan Tangkap di Laut Lepas. Peraturan menteri ini berlaku bagi setiap orang atau setiap kapal berbendera Indonesia yang melakukan penangkapan ikan dan/atau pengangkutan ikan di laut lepas sebagaimana diatur pada Pasal 2. Terdapat beberapa prosedur yang harus dipenuhi setiap individu atau perusahaan yang ingin menangkap ikan di laut lepas. Peraturan Menteri ini sebagaian besar mengatur hal-hal yang bersifat administratif, seperti pendaftaran, izin, pengadaan dan pemeriksaan fisik kapal penangkap ikan. Selain itu, peraturan ini juga memuat aturan tentang penanaman modal bagi setiap orang yang ingin berusaha dalam bidang perikanan.

Peraturan ini tidak hanya mengatur hal-hal yang berkaitan dengan bisnis perikanan di laut lepas, tetapi peraturan ini juga mengatur tentang upaya konservasi sumber daya ikan di laut lepas. Pada Bab IX Peraturan Menteri ini dapat ditemukan berbagai tindakan yang harus dilakukan sebagai bentuk konservasi sumber daya ikan di laut lepas.

Peraturan ini mengatur jenis ikan yang tidak boleh ditangkap sebagaimana telah ditentukan dalam Pasal 73 ayat (1) bahwa setiap kapal penangkap ikan yang memiliki Surat Izin Penangkapan Ikan (SIPI) di Wilayah Pengelolaan Perikanan Negara Republik Indonesia wajib melakukan tindakan konservasi terhadap jenis spesies tertentu yang terkait secara ekologi dengan tuna, yang ditetapkan oleh Regional Fisheries Management Organization. Spesies yang dimaksud adalah sebagai berikut:

1) ikan hasil tangkap sampingan (bycatch) berupa hiu monyet (thresher shark);

2) non-ikan yang tertangkap secara tidak sengaja (incidental catch) berupa burung laut, penyu laut, dan mamalia laut termasuk paus; dan

3) hasil tangkap sampingan (bycatch) yang secara ekologi terkait dengan perikanan pukat udang dan perikanan pukat berupa ikan campur. 

meliputi:47

Tindakan konservasi terhadap spesies yang telah disebutkan di atas

1) melepaskan ikan yang tertangkap jika masih dalam keadaan hidup;

2) melakukan penanganan dan/atau menyiangi ikan yang tertangkap dalam keadaan mati dan mendaratkannya dalam keadaan utuh;

3) melakukan pencatatan jenis ikan yang tertangkap dalam keadaan mati, dan melaporkannya kepada Direktur Jenderal melalui kepala pelabuhan pangkalan sebagaimana tercantum dalam SIPI; dan

4) khusus untuk spesies perikanan pukat udang dan perikanan pukat ikan campuran yang dimanfaatkan untuk kebutuhan konsumsi dan sebagai bahan baku tepung ikan, maka nahkoda perlu melapor kepada Direktur Jenderal melalui kepala pelabuhan pangkalan sesuai dengan SIPI.

Sanksi yang diberikan terhadap kapal penangkap ikan yang melanggar hal-hal yang telah ditentukan di atas maka akan dikenai sanksi administratif. Kelemahan peraturan ini yaitu sulit untuk membuktikan ikan yang merupakan hasil tangkap sampingan atau tidak sengaja. Hal tersebut dapat dijadikan alasan untuk menangkap ikan-ikan yang dilindungi. Peraturan ini juga tidak mengatur tentang pengawasan bersama dengan organisasi regional.

\section{Penutup \\ 1. Kesimpulan}

Berdasarkan uraian pada bagian pembahasan di atas, maka dapat diambil kesimpulan sebagai berikut:

a. ada beberapa peraturan internasional yang dapat dijadikan sebagai dasar bagi setiap pihak yang memiliki kapasitas untuk menjaga konservasi ikan di laut lepas. Pasal 117 dan Pasal 118 UNCLOS 1982 bagian ini juga mengamanatkan kerja sama negara-negara dalam konservasi dan pengelolaan sumber kekayaan hayati di laut lepas. Negara bendera atau setiap pihak dapat melakukan tindakan yang berkaitan dengan perlindungan sumber daya hayati di laut lepas sebagaimana telah diatur dalam Pasal III ayat (1), (7), (8) FAO Compliance Agreement 1993. Bab III UN Fish Stocks Agreement 1995 menyebutkan bahwa, "mekanisme untuk kerja sama internasional dalam pengelolaan jenis-jenis ikan yang bermigrasi jauh dan jenis-jenis ikan yang bermigrasi terbatas, baik secara langsung maupun tidak melalui kesepakatan atau organisasi pengelolaan perikanan regional dan sub-regional. Code of Conduct for Responsible Fisheries (CCRF) 1995 merupakan buku petunjuk yang sangat penting

\footnotetext{
${ }^{47}$ Pasal 73 ayat (3) dan Pasal 74 ayat (1), (2) Peraturan Menteri Nomor Per. 12/ Men / 2012 Tentang Usaha Perikan Tangkap di Laut Lepas
} 
bagi seluruh masyarakat perikanan, baik nasional maupun internasional untuk menjamin kegiatan perikanan yang berkelanjutan dan bertanggung jawab di wilayah pesisir dan laut. FAO IPOA-IUU Fishing 2001 merupakan instrumen hukum internasional yang bersifat sukarela (voluntary instrument) dan mengatur tanggung jawab (responsible) berbagai negara dalam pemberantasan IUU fishing.

b. Indonesia telah membuat regulasi tentang perikanan melalui UndangUndang Nomor 31 Tahun 2004 dan Undang Nomor 45 Tahun 2009, serta membuat peraturan menteri tentang penangkapan ikan di laut lepas yaitu Peraturan Menteri Kelautan dan Perikanan Nomor PER.03/MEN/2009 tentang Penangkapan Ikan dan/atau Pengangkutan Ikan di Laut Lepas dan Peraturan Menteri Nomor Per.12/Men/2012 tentang Usaha Perikan Tangkap di Laut Lepas. Indonesia telah meratifikasi beberapa peraturan internasional yang berkaitan dengan pengelolaan stok ikan di laut lepas serta Indonesia juga telah bergabung dalam beberapa organisasi regional yang bergerak dalam bidang pengelolaan konservasi ikan di laut lepas.

c. Indonesia memiliki kedudukan untuk berperan penting menjaga konservasi sumber daya ikan di laut. Indonesia telah menjadi pihak pada dua RFMOs yang ada, yaitu Indian Ocean Tuna Commission (IOTC) dan Commission for the Conservation of Southern Blufin Tuna (CCSBT), serta menjadi cooperating non-members pada Commission for the Conservation and Management of Highly Migratory Fish Stocks in the Western and Central Pacific Ocean (WCPFC).

\section{Saran}

Pemerintah Indonesia harus mampu memanfaatkan keikutsertaan tersebut serta meningkatkan pertukaran informasi, data, riset perikanan, pemberantasan penangkapan ilegal, dan bentuk-bentuk kerja sama lainnya. Pemerintah Indonesia seharusnya tidak sebatas menghadiri setiap pertemuan yang dilakukan oleh organisasi regional/multilateral tersebut, tetapi sekembalinya dari pertemuan tersebut menghasilkan dalam kebijakan teknis untuk mengatasi permasalahan perikanan yang sampai saat ini belum tuntas.

\section{Daftar Pustaka}

\section{A. Buku}

Anwar, Chairul, 1989, Hukum Internasional Horizon Baru Hukum Laut Internasional Konvensi Hukum Laut 1982, Jakarta: Penerbit Djambatan.

Churchill, R. R, and A.V. Lowe, 1983, The Law Of The Sea, Manchester: Manchester University Press. 
Mauna, Boer, 2005, Hukum Internasional, Pengertian Peranan dan Fungsi Dalam Era Dinamika Global, Edisi ke-2, Bandung: Penerbit PT. Alumni.

Siombo, Marhaeni Ria, 2010, Hukum Perikanan Nasional dan Internasional. Jakarta: Gramedia Pustaka Utama.

Starke, J.G., 1988, An Introduction to International Law, London: Butterworths.

Thontowi, Jawahir dan Pranoto Iskandar, 2006, Hukum Internasional Kontemporer, Bandung: PT. Refika Aditama.

Tetley, William, 2002, International Maritime and Admiralty Law. International Shipping Publication, Les Editions Yvon Blais Inc.

Tirtamulia, Tjondro, 2011. Zona-Zona Laut UNCLOS, Surabaya: Brilian Internasional.

\section{B. Jurnal}

Delgado, C.L, N. Wada, M.W. Rosegrant, S. Meijer and M. Ahmed dalam Purwito Martosubroto, Perkembangan Pengelolaan Perikanan Global. Jurnal Hukum Internasional (Indonesian Jurnal of International Law). Volume 1 Nomor 3. April 2004.

Yulianto, Hari, Qua Vadis Arah Kebijakan Perikanan Indonesia? Tantangan dalam Perspektif Hukum dan Kepentingan Nasional (bagian I). Opinio Juris, Vol. I. Januari-Maret 2010.

Andrianto, Lucky, Implementasi Code of Conduct For Responsible Fisheries dalam Perspektif Negara Berkembang, Jurnal Hukum Internasional (Indonesian Jurnal of International Law), Volume 2 Nomor 3. April 2005.

Ariadno, Melda Kamil. Kepentingan Indonesia Dalam Pengelolaan Perikanan Laut Bebas.Jurnal Hukum Internasional (Indonesian Jurnal of International Law). Volume 2 Nomor 3 April 2005.

Martosubroto, Purwito, Implementing of the Code of Conduct for Responsible Fisheries in the Marine Fisheries Sector, Jurnal Hukum Internasional, Vol 2. No. 3, April 2005.

\section{Internet}

James H. Tidwell \& Geoff L. Allan, Ecological and economic impacts and contributions of fish farming and capture fisheries, http://www.nature.com/embor/journal/v2/n11/full/embor285.html

Global fisheries face the ecosystem challenge. ftp://ftp.fao.org/docrep/fao/011/aj982e/aj982e09.pdf, diakses pada tangal 10 Juni 2015 
Conservation Science Institute, Destructive Fishing Practices, 2009, http://www.conservationinstitute.org/ocean_change/Fisheries/destructi vefishingpractices.htm

Pandapotan Sianipar, Aspek Legal Instrumen Hukum Internasional Implementasi Pengawasan Sumberdaya Perikanan, http://djpsdkp.kkp.go.id/index.php/arsip/file/137/aspek-legalinstrumen-hukum-internasional-implementasi-pengawasansumberdaya-perikanan.pdf/

\section{Peraturan Hukum Internasional}

United Nations Convention on The law of Sea (UNCLOS) 1982

Agreement to Promote Compliance with International Conservation and Management Measures by Fishing Vessels on the High Seas (FAO Compliance Agreement) 1993

Agreement for the Implementation of the United Nations Convention on The Law of The Sea of 10 December 1982 Relating to The Convention and Management of Stadding Fish Stocks and Highly Migratory Fish Stocks (UN Fish Stocks Agreement) 1995

Code of Conduct for Responsible Fisheries, Food andAgriculture Organization 1995

Agreement on Port State Measures to Prevent, Deter and Eliminate Illegal,

Unreported and Unregulated Fishing, Food and Agriculture Organization 2009;

\section{E. Peraturan Hukum Nasional}

Undang-Undang Nomor 45 Tahun 2009 tentang Perikanan (Lembaran Negara Republik Indonesia Tahun 2009 Nomor 154, Tambahan Lembaran Negara Republik Indonesia Nomor 5073)

Peraturan Menteri Kelautan dan Perikanan Republik Indonesia No. PER.03/MEN/2009 Tentang Penangkapan Ikan dan/atau Pengangkutan Ikan

Peraturan Menteri Nomor Per. 12/ Men / 2012 Tentang Usaha Perikan Tangkapdi Laut Lepas ( Berita Negara Republik Indonesia Tahun 2013 Nomor 81) 